\title{
The Tradition of Medication In Manuscripts: Efforts To Fight Pandemics By Medicinal Heritage In Manuscripts
}

\author{
Dede Hidayatullah ${ }^{1}$, Agus Yulianto ${ }^{2}$ \\ \{dayatdh@gmail.com\} \\ Balai Bahasa Kalimantan Selatan, Indonesia
}

\begin{abstract}
Old manuscripts are the heritage of the past that capture life, culture, and science, as well as medication. This heritage must exist and live in the next generation. The objective of this study is to examine the healing practice in the manuscripts in South Kalimantan (Banjar Manuscripts). The data source of this research is from the Medicinal Mantra Manuscript, Mystical Mantra Manuscript, and the Astambul Manuscript. The method of the research is descriptive. The researchers are collecting medicinal data from the two manuscripts, then selecting the data according to the research needs. The results show that there is a healing practice for various diseases such as fever, respiratory illness, lower back pain, toothache, headaches, eye disease, and muscle pain. There are three mediums of healing, namely herb, mantra (spell), and azimat (amulet). The forms of medicine used are majun (herb drinking), wadak (herb powder), compress, ingestion, and reciting the medium such as a prayer, isim, or mantra. The treatment in the Banjar manuscript will be useful for alternative treatment of the Covid-19 pandemic. Hopefully, there will be further research that discusses medicinal manuscripts in the medical field.
\end{abstract}

Keywords: Manuscripts, medication, cultural heritage

\section{Introduction}

Coronavirus infection or COVID-19 (Corona Virus Disease 2019) began to spread in Wuhan city China at the end of December 2019. This virus is spreading very quickly and has spread to almost all countries, including Indonesia, in just a few months. This situation has led several countries to implement policies to impose lockdown to prevent the spread of the Coronavirus. In Indonesia, the government has imposed a Large-Scale Social Restriction (PSBB) policy to contain the spread of this virus.

Coronaviruses are the viruses that infect the respiratory system. In many cases, they only cause mild respiratory infections, such as the flu. However, these viruses may cause serious respiratory infections, such as lung infections (pneumonia). In general, there are three symptoms of the Corona virus infection, namely fever (body temperature above 38 degrees Celsius), dry cough, respiratory illness. The other symptoms of Corona virus infection are diarrhoea, headaches, conjunctivitis, a loss of the sense of taste or smell, rashes on the skin, although it rarely occurs.[1] 
On September 9, 2020, the number of recovered patients of Covid-19 has reached 145,200 nationally. Maintaining immunity is the keyword to recover from Covid-19. The recovered patients of covid-19 is due to immunity rises. Traditional medicine is one of the alternatives in increasing immunity (2020). [1]

There are several studies on traditional medical treatment either in Indonesia or in other countries. Puspitawati, S. Ekomila, and N. Hasanah (2013) [2] researched ethnomedicine as an alternative solution to solve economic and public health problems in Bagan Village, Percut Sei Tuan District, Deli Serdang Regency. S. Oknarida, F. Husain, and H. Wicaksono (2019) [3] examined medicinal plants in the Colo Village, Dawe District, Kudus Regency from Mbah Yai Yanto, a traditional healer who applies traditional healing methods to treat diseases. Julius dan Muswita (2013) [4] examined the traditional medication in the Batin tribe of Jambi that applied medicinal plants. V. Anggi [5] researched on the Red Gedi Leaf as a traditional breast cancer treatment in Maku Village, Central Sulawesi Province. E. AM. Zuhud (2009) [6] studied tropical forests as a reserve of natural medicine. Plotkin (1998) [7] was interested in studying medicinal plants in Thailand forests. S. Albert and G. Kuldip (2006) [8] studied traditional medication in the Jaintia Tribe. Meanwhile, M. Viraponse (2006) [9] wrote about the traditional healing system of the Kui tribe in Northern Thailand.

Besides, there were also studies on traditional medication in manuscripts, such as D. Hidayatullah. He studied mantra and treatment (tatamba) on five Banjar manuscripts (2018) [10] and edited the manuscript of healing mantra (2019) [11]. He also studied the mystical mantra manuscripts (2016) [12] and prayers for protection from the disaster manuscript (2017) [13] that contained mantra. Junaidi [14] studied ethnomedicine practice in Malay society in a manuscript written by Raja Haji Ahmad ibn Raja Haji Hasan (Raja Haji Ahmad Tabib) in Penyengat Island. D. Susena, Pramono, and H. N. Hidayat (2013) [15] conducted an inventory study of the medicinal manuscript in Minangkabau society and conducted ethnomedicine research on those manuscripts. Kasrina (2015) [16] (2015) examined the use of traditional medicinal plants in the Ka Ga Nga manuscript. Nawangningrum, Widodo, Suparta, \& Holil (2004) [17] classified traditional medicines and diseases in the manuscripts of the Faculty of Humanity, Universitas Indonesia. Hamid, Faisal, \& Fauzi (2012) [18] studied Malay traditional treatment in the Kitab Tib (Book of Healing) by Haji Ismail bin Haji Mustafa Pontianak.

\section{Research Methods}

The object of this research is the treatment in the Medicinal Manuscripts, medical manuscripts, and the Astambul manuscript. Hidayatullah has edited the two manuscripts (2019) [19] in the form of Editing of Medical Manuscripts in South Kalimantan. The owners of these texts are different. The owner of the medicinal manuscript is Abu Najib. He keeps the manuscript at his house in the Banjar Traditional House, Selong, Jalan Martapura Lama No. 28, Martapura Barat Subdistrict, South Kalimantan. Besides, the owner of the Istambul manuscript is Salman Alfarisi in Pingaran Village, Astambul Subdistrict, Banjar Regency.

This research will study the practice of ethnomedicine in 2 manuscripts, namely Medicinal Mantra Manusript, and Astambul manuscript. Studies and research on medicinal manuscripts must continue to describe and explore various heritages and local wisdom in the health sector, especially during the Covid-19 pandemic like today.

The essence of traditional medicinal practice is a treatment process that comes from existing traditions in society. Payyappallimana (2010) [20] mentions the term of traditional medicine as 
TRM. There are also other names used, such as herbal medicine, folk medicine, and ethno medicine. From the description above, traditional medicine has attracted researchers' attention, either medical experts or anthropologists, to study deeper the various sides of traditional medicine from the perspective of the supporting society. The ethnomedicine study refers to traditional medical practices related to interpretation [14].

This research uses qualitative method with ethnomedicine approach. The main data of this research is the editing texts of the translation by Dede Hidayatullah. The data consists of two manuscripts. They are Medicinal Manuscripts, and the Astambul Manuscripts. The technique of this research applies the text critique to study the content of the manuscripts so that other readers can easily understand the content of the text. The researcher describes data of medicines and diseases in the two manuscripts then classifies the data according to the kind of treatment. Then the next step is data analysis according to the method of treatments and diseases. The researchers then compared the results of these data with existing research, either in its relation to oral literature research or medicinal research.

\section{Results and Discussion}

\subsection{Disease and Medicine}

\section{Identification of diseases in the Astambul manuscript}

The Astanbul manuscript consists of 39 chapters, there are 23 diseases, such as vitality problem, dysentery, body supplement (immunity), impotence, small-sized genital, blood in the stool, boil in children, chest pain (heart).

\section{Identification of diseases in the Medicinal Mantra Manuscripts}

The Medicinal Mantra Manuscript consists of seventy-six chapters. Sixty-six chapters are about medication. Diseases in the Medicinal Mantra manuscript are purulent inflammation, sore eyes, flu, headache, lower back pain, fever, body aches (stiff muscle and rheumatic), menstrual cramps, diarrhea, inflammation, wounds, fever and respiratory illness, stomachache, vitality medicine, vitality problem, chest pain (heart), bladder pain, asthma and tuberculosis, all diseases, epilepsy, dental treatment, an anti-inflammatory drug, bone pain, heart problem, urologic diseases, infertility, semen production, heartburn, and fatigue.

\section{Identification of treatment in the Astambul manuscript}

The treatments in the Astambul manuscript are:

a. There are five rajahs used as a treatment, such as to enlarge the size of genitals [21], rajah for impotence [21], rajah for stimulating women's lust, and stomachache. In the manuscript, there are two kinds of Rajah. It is in Arabic letters and from the name of Allah.

b. There are nine amulets as medicine. These amulets are for treatment of various diseases such as impotence, male vitality, sexual intercourse duration and orgasm, boil on children and all diseases.

c. There is a recitation for the treatment of all diseases, impotence, possessed by jinn. The Astambul manuscript consists of two recitations, namely the recitation of Quran verses such as Surah al-An'am verses 103-104 for the treatment of evil spirit possession to a person and to treat the duration of sexual intercourse, and Arabic recitation that contains the name of the jinn king for all medicine. 
d. The antidote for healing wounds, chest pain (respiratory illness), and snake venom. All of the antidote in the Astambul manuscript (NA) end with the creed 'owing to the blessing of Lâ ilâ ha illa 1_Lâh Muhammaddu r-rasûlullâh.'

e. The medicines derive from plants and animals for vitality while having sexual intercourse, stomachache, and blood in the stool, body immunity (body strength), and medication for all diseases. Medicines found in the Astambul manuscript (NA) such as syifa oil, chicken eggs, honey, turmeric, pepper, ginger, galingale, galangal, cinnamon, garlic, nutmeg, black cumin, air plant leaves, agarwood (Aquilaria malaccensis), betel (Piper betle), lime (Citrus aurantifolia), , coconut (Cocos nucifera)

f. Rasya is an ingested fluid made of recited mercury. The use of Rasya is usually for invulnerability (kekebalan). In this Astambul manuscript, there is a description that Rasya can be helpful for vitality while having sexual intercourse and medicine for a hernia. Besides, Astambul Manuscript (NA) describes how to make Rasya, use it inside the body, and how to get it out of the corpse.

\section{Identification of medicine in the Medicinal Mantra Manuscript}

a. The use of Rajah for healing stomachache, cough, urinary tract, asthma or respiratory illness, and all diseases. There are two kinds of Rajah in the Medicinal Mantra Manuscript (NMP manuscript); they consist of Arabic letters and numerals, and they come from verses of the Quran and prayers in Arabic.

b. The use of amulets is for protecting oneself from infection to all diseases and to treat infertility. These amulets are from Arabic letters and numerals, as well as verses of the Quran. The use of the Arabic letter and numeral amulets are to heal all diseases, while amulets from the Quran verses are to treat infertility.

c. The recitation is the treatment for fever, all diseases, and sore eyes. This kind of medicinal recitation originates from; [22].

d. The antidote is the treatment for the large boil, fever, wounds, all diseases, respiratory illness, fatigue and headaches, lower back pain, epilepsy, toothache. Not of all antidotes in this Medicinal Mantra Manuscript use the Islamic creed (shahada).'anu berkat Lâ ilâ ha illa 1_Lâh Muhammaddu r-rasûlullâh, but all of these antidotes have words that refer to Islam, such as the sentence 'Bismi l-Lâhi r-rahmâni r-rahîm, tawar Allah, tawar rasulullah, Ilâhu 1-haq Ilâhu 1-muthlak.

e. Medicines originate from plants and animals. The use of these medicines is to treat back pain, fatigue, menstruation, diarrhea, inflammation, fatigue, sore eyes, flu, and heartburn. Medicines in this Medicinal Mantra Manuscript (MP) are turmeric (curcuma domestica),(curcuma domestica), vinegar, tamarind(Tamarindus Indica), sugar, galangal (alpinia galangal), white pepper (Piper nigrum), chicken eggs, shallot (allium cepa fa ascalonicum), lime (aevum cretaceum), honey, grass, charcoal, husk, coconut milk, tobacco, rice husk ash, duck eggs, soy sauce, beef oil, nutmeg (myristica fragrans), fennel (foeniculum vulgare), cinnamon (cinnamomum burmani), cumin (carum roxburghianum), lime (citreum), salt $(\mathrm{NaCl})$, resin (resina), betel (piper betle), sesame (sesamum orientale), clove (syzygium aromaticum), cardamom (elletaria cardamomum), hazelnut (aleurites moluccana), chilie (capsicum annuum), sandalwood (santalum album), gall oak (quercus lusitanica), rice (oryza), and areca nut (areca vestiaria giseke). 


\subsection{Healing practice}

\section{Healing practice with rajah}

This healing practice with rajah takes several ways, namely

a. The use of Rajah is to treat an object such as to resize the male genital [21].

b. Writing Rajah on an object such as paper or cloth, then put it in water, and then drink the water. [21] [23].

c. The use of rajah is to treat colic by writing it on foods such as green coconut mixed with black cumin and air plant leaves [21].

d. Writing rajah on a bowl, or white plate, or dish and then fill it with water. Then drink the water to treat the cough [23].

The treatment using rajah is useful to treat diseases such as cough and for the prevention of all diseases.

\section{Healing practice with Amulet (Azimat)}

From the previous description, generally, the Azimat (Amulet) is writing in Arabic letters on an object such as paper that is easy to carry. A user must take the amulet when carrying out activities related to diseases such as amulets in sexual intercourse for a long duration. Then the user hung this amulet on the waist; [21] it is also the same as the amulet for infertile women, which must place it on the stomach during sexual intercourse on Thursday night [23].

Besides, a user can also use an amulet on a pillow or a bottle to repel all diseases [23]. The amulet in Medicinal Mantra Manuscript is not only in Arabic letters and numbers but also from Al-quran.

\section{Healing practice with Recitation}

There are several ways of treatment using the recitation.

a. The treatment is using recitation by blowing directly to an object, like the treatment of headaches and eyes. [23]. The treatment practice is reading a recitation, then blowing the object for healing. A shahada (Islamic creed) follows the blowing, take a deep breath, then recites $\mathrm{Hu}$. After exhaling the breath then ends with Allah. When exhaling, there is a determination in the heart to heal disease.

b. Doing a handshake while reading the recitation with the person under treatment [23].

c. While reading the recitation, place the hand on the object under treatment, as in the treatment of headache. [23].

d. Reciting on medicine, such as grass and limestone for menstrual cramps, then drink the potion,

e. Reading a recitation on a medium such as a piece of cotton, then make it to be ingested medicine (swallow directly without chewing) [21].

f. Reading a recitation while doing a treatment, then rubbing the object of treatment for protection from disease, such as eye disease. The recitation is Salawat on two thumbs when the first call of prayer saying Muhammad at the verse Asyhadu Anna Muhaamadar Rasulullah. Then the two thumbs rubbed on the eye three times in succession. [23].

g. When doing a recitation, the eyes look at the sick part. [21].

h. Reading a recitation while taking the medicine 


\section{Healing practice with Antidote (Penawar)}

There are several treatments using antidotes, namely:

a. Reciting antidote directly and then blowing on the healing object such as heartburn, wound healing [21], boil, lower back pain, fever, and respiratory illness. [23].

b. Reciting the antidote on the water and then drink or wipe the water to the healing object, for example, the treatment of headache by rubbing the water on the head.

c. Recitation while doing an activity, such as doing recitation while brushing the teeth to heal the toothache [23].

\section{Medicinal Practice originates from plants and animals}

There are several ways of medicinal practice originates from plants and animals.

a. Compress (a kind of paste made of spices such as turmeric, vinegar, and limestone, then place it over the crown [23].

b. Herb powder (a kind of cream made from spices such as pepper, red onion, rice husk ash, and lime which is spread all over the body), for inflammation medicine, it can also be rubbed around the eyes to make eye shadow to treat eye diseases.[23].

c. A majun is like rounded herbal medicine for drinking consumption.

d. Herb drinking is for body aches, diarrhea, and lower back pain [23], and vitality medicine [21].

e. Making herb powder and drinking with recitation.

From the explanation above, the researchers conclude that there are several forms of treatment in the NA and MP manuscripts. The forms of medicine are rounded herb drinking (majun), herb powder (wadak), herb compress (pupuk), ingested medicine (untalan), rasya, amulet, rajah, antidote, recitation. These treatments have given the addition to Daud classification (1997) [24]. There are several forms of medicine that the Banjar people know, namely; (1) Majun consists of several thickened and rounded spices, and it is used by swallowing.; (2) Herb powder (wadak), it consists of several thickened and rounded spices; (3) compress (pupuk), similar to herb powder, but it is used by spreading on the crown for healing fever or headaches; (4) Ingested medicine (lungsur) is the kind of wooden roots put in cold water, and then the water is used for drinking; (5) treatment applies recitation, isim, or mantra to an object. From the data above, lungsur is not from the Medicinal Mantra (MP) [22] and Astambul Manuscript NA. However, there are types of additional treatment, namely treatment with rajah, amulet, rasya, ingested medication, and medication using recitation to ingested objects such as antidote, reading, or rajah.

The Banjar people are known for their religiosity, a society that has strong Islamic characteristics. Likewise, the religiosity gives influence in terms of medicinal practice. This religiosity also appears in medicinal practice. From several types of treatment in the NA and MP manuscripts; it shows the strong influence of Islam. Even the antidote is an old religious heritage such as kaharingan and Hinduism ends with the creed 'owing to the blessing of 'berkat Lâ ilâ ha illa 1_Lâh Muhammaddu r-rasûlullâh, or the words that refer to Islam, such as the sentence 'Bismi 1-Lâhi r-rahmâni r-rahîm, tawar Allah, tawar rasulullah, Ilâhu 1-haq Ilâhu 1muthlak. The fact shows a cultural compromise between old religions in South Kalimantan, such as Kaharingan or Hinduism and Islam [25].

Treatment using rajah, amulet, and recitation shows the religiosity of the Banjar people. It is a fact that medicine has a role in the element of belief. Either rajah written on medicine or amulets carried on the body and recitation on water. It gives confidence for healing because of the amulets, rajah, and readings come from the Quran or Salawat and prayers. Medicinal 
treatment using rajah, amulets such as babatsal, and drinking water from recitation still exist today in the Banjar people. The kind of medicinal practice is an alternative way that gives a strong influence on the element of belief. Medicinal practice using herbs, plants, and animals shows evidence of the relation of the Banjar people to nature.

Likewise, during this pandemic, We should increase our confidence in our hearts through recitation that can keep us from all diseases, taking medicines made of plants and animals as immune boosters, and continuing to keep our distance and wearing masks.

\section{Conclusion}

In the NA and MP manuscripts, there are several treatments such as rajah, amulet, recitation, antidote, rasya, and medicines made from plants and animals such as turmeric (curcuma domestica), vinegar, tamarind (Tamarindus Indica), sugar, galangal (alpinia galangal), white pepper (Piper nigrum), chicken eggs, shallots (allium cepa fa ascalonicum), lime (aevum cretaceum), honey, grass, charcoal, husks, coconut milk, tobacco, rice husk ash, duck egg, soy sauce, beef oil, nutmeg (myristica fragrans), fennel (foeniculum vulgare), cinnamon (cinnamomum burmani), cumin (carum roxburghianum), lime (citreum), salt $(\mathrm{NaCl})$, resin (resina), betel (piper betle), sesame (sesamum orientale), clove (syzygium aromaticum), cardamom (elletaria cardamomum), hazelnut (aleurites moluccana), chilies (capsicum annuum), sandalwood (santalum album), gall oak (quercus lusitanica), rice (oryza), and areca nut(areca vestiaria giseke).

There are several forms of treatment found in these NA and MP manuscripts, namely herb drinking (majun), herb powder (wadak), compress, ingested medicine, rasya, and medicinal practice, such as recitation or rajah. This medicinal practice is useful for the treatment of various diseases such as purulent inflammation, sore eyes, flu, headache, lower back pain, fever, body aches (stiff muscle and rheumatic), menstrual cramps, diarrhea, inflammation, wounds, fever and respiratory illness, stomachache, vitality pill, vitality problem, chest pain (heart), bladder pain, asthma and tuberculosis, all diseases, epilepsy, dental treatment, obat bengkak, bone pain, heart problem, urologic diseases, infertility, semen production, heartburn, and fatigue.

Medicine in the NA and MP manuscripts integrates elements of religious beliefs as part of the healing. Medicinal practice using recitation, Rajah, and amulet gives confidence to a sick person for healing. Treatment using rajah, amulet, and recitation shows the religiosity and belief of the Banjar people. This belief is a crucial part of medicinal practice. Medicines using spices, plants, and animals show the benefit of nature, and the close relation of the Banjar people to natural resources, while the treatment with antidotes is a cultural compromise between Islam and the old religion in South Kalimantan.

\section{Suggestion}

As the first step of medical research in manuscripts, it requires further study, especially concerning medicinal plants for alternative healing in this pandemic.

\section{References}

[1] C. I. Tim, “Alasan di Balik Imunitas Tubuh Kuat Bisa Cegah Covid-19,” 2020.

[2] Puspitawati, S. Ekomila, and N. Hasanah, "Etnomedisin Sebagai Solusi Alternatif Pada Permasalahan Ekonomi dan Kesehatan Masyarakat di Desa Bagan Kecamatan Percut Sei Tuan, Kabupaten Deli Serdang,”JUPIIS, vol. 5, no. 1, pp. 116--126, 2013. 
[3] S. Oknarida, F. Husain, and H. Wicaksono, "Kajian Etnomedisin Dan Pemanfaatan Tumbuhan Obat Oleh Penyembuh Lokal Pada Masyarakat Desa Colo Kecamatan Dawe Kabupaten Kudus," Solidar. J. Educ. Soc. Cult. 7 (2), 480-500, vol. 7, no. 2, pp. 480-500, 2019.

[4] Jalius and Muswita, "Eksplorasi Pengetahuan Lokal tentang Tumbuhan Obat di Suku Batin, Jambi," Biospecies, vol. 6, no. 1, pp. 28-36, 2013.

[5] V. Anggi, "Penerapan Tanaman Daun Gedi Merah Sebagai Pengobatan Tradisional Antikanker Payudara di Desa Maku Provinsi Sulawesi Tengah," Celeb. Abdimas, vol. 1, no. 2, pp. 96-100, 2019.

[6] E. AM.Zuhud, "Potensi Hutan Tropika Indonesia sebagai Penyangga Bahan Obat Alam untuk Kesehatan Bangsa,” J. Bahan Alam Indones., vol. 6, no. 6, pp. 227-232, 2009.

[7] Plotkin, "The Conservation of Medicinal Plants, Proceedings of International Consultation, 21 - 27 March 1988.," in Traditional Knowledge of Medicinal Plants. The Search for New Jungle Medicines., 1988.

[8] S. Albert and G. Kuldip, "Traditional use of medicinal plants by the Jaintia Tribes in North Cachar Hills district of Assam, Northeast India,” J. Ethnobiol. Ethnomedicine 2(1)33, vol. 2, no. 1, p. 33, 2006.

[9] M. Virapongse, "Ethnomedicine adn Materia Medica Used by Kui Traditional Healer in Northeast Thailand. Khon Kaen: University.," Khon Kaen, 2006.

[10] [10] D. Hidayatullah, "Tatamba (Pengobatan) dalam Naskah Banjar," Kelasa, vol. 13, no. 2, pp. 129$138,2018$.

[11] D. Hidayatullah, "Mantra pengobatan dalam naskah Banjar," Naditira Widya, vol. 13, no. 1, pp. 41$56,2019$.

[12] D. Hidayatullah, "Naskah mantra mistik: Kodikologi, suntingan dan isi teks," Undas, vol. 12, no. 1, pp. 117--133, 2016.

[13] D. Hidayatullah, "Mantra dalam naskah 'wirid Doa Tolak Bala': Deskripsi, isi, dan suntingan teks," Kandai, vol. 13, no. 1, pp. 121--136, 2017.

[14] Junaidi, "Praktik Etnomedisin dalam Manuskrip Obat-Obatan Tradisional Melayu," Manuskripta, vol. 6, no. 2, pp. 59-77, 2016.

[15] D. Susena, Pramono, and H. N. Hidayat., "Pengobatan Tradisional dalam Naskah-Naskah Minangkabau," Wacana Etn., vol. 4, no. 2, pp. 134-152, 2013.

[16] Kasrina, "Pemanfaatan Tumbuhan Obat Tradisional oleh Masyarakat Etnis Serawai Berbasis Naskah Kuno Ka Ga Nga di Desa Kampai Talo Kabupaten Bengkulu Selatan,” in Prosiding Semirata 2015 bidang MIPA BKS-PTN Barat Universitas Tanjungpura Pontianak, 2015, pp. 36-46.

[17] D. Nawangningrum, S. Widodo, I. M. Suparta, and M. Holil, "Kajian Terhadap Naskah Kuna Nusantara Koleksi Fakultas Ilmu Pengetahuan Budaya Universitas Indonesia: Penyakit dan Pengobatan Ramuan Tradisional," Makara, Sos. Hum., vol. 8, no. 2, pp. 45-53, 2004.

[18] A. Hamid, F. Faisal, and N. W. Fauzi, "Perubatan Melayu tradisional: Ktab Tibb Pontianak (Malay Traditional Medicine: Kitab Tibb Pontianak),” Al-Tamaddun, vol. 7, no. 1, pp. 149-162, 2012.

[19] D. Hidayatullah, Suntingan Teks Naskah Pengobatan DI Kalimantan Selatan. Jakarta: Perpustakaan Nasional Republik Indonesia, 2019.

[20] U. Payyappallimana, "Role of Traditional Medicine in Primary Health Care: An Overview of Perspectives and Challenges. 14. 57-77.," Yokohama J. Soc. Sci., vol. 14, no. 6, pp. 57-77, 2010.

[21] Naskah Astambul. Martapura.

[22] D. Hidayatullah, "Mantra Pengobatan dalam Naskah Banjar (Healing Mantra in Banjarese Manuscript)," Naditira Widya, vol. 13, no. 1, p. 41, 2019.

[23] Mantra Pengobatan. Martapura.

[24] A. Daud, Islam dan masyarakat banjar. Jakarta: PT. Raja Grafindo Persada, 1997.

[25] A. Yulianto, "Mantra Banjar: Suatu Kompromi Budaya.," Naditira Widya, vol. 5, no. 2, pp. 133-140, 2011.

[26] Sunarti, Purlansyah, S. Seman, S. Maswan, and M. Saperi, Sastra lisan Banjar. Jakarta: Pusat Pembinaan dan Pengembangan Bahasa, 1978.

[27] M. Mugeni et al., Mantra Banjar, 2nd ed. Banjarbaru: Balai Bahasa Kalimantan Selatan, 2006. 